\title{
Oxidative stress and antioxidant defenses after starvation in Oncorhynchus mykiss (Walbaum, 1792) larvae reached free swimming stage
}

\section{Serbest yüzme safhasına ulaşan Oncorhynchus mykiss (Walbaum, 1792) yavrularında açlık sonrası oksidatif stres ve antioksidan savunmalar}

\author{
Hatayi Zengin ${ }^{1}$ \\ 'Department of Mathematics and Science Education, Faculty of Education, Cumhuriyet University, 58140, Sivas, Turkey iD https://orcid.org/0000-0002-8148-4056
} hzenginster@gmail.com

Received date: 03.04 .2018

Accepted date: 27.07 .2018

How to cite this paper:

Zengin, H., (2018). Oxidative stress and antioxidant defenses after starvation in Oncorhynchus mykiss (Walbaum,

1792) larvae reached free swimming stage. Ege Journal of Fisheries and Aquatic Sciences, 35(4), 387-396.

DOI: 10.12714/egejfas.2018.35.4.04

\begin{abstract}
Oxidative stress and antioxidant enzyme activities after starvation of Oncorhynchus mykiss larvae were studied. Just after yolk-sac absorption, free-swimming larvae were maintained under starved condition for a period of 21 days. Sampling of fish were carried out every week and their whole bodies were used for the analysis of superoxide dismutase (SOD), catalase (CAT), glutathione peroxidase (GSHpx), glutathione reductase (GR), glutathione S-transferase (GST) and also analysis of malondialdehyde (MDA) and glutathione (GSH). Antioxidant enzymes activities showed that GST and CAT had the highest activity, whilts SOD and GSHpx had the lowest activity of all the enzymes assayed in 14 day free swimming starved larvae. SOD activity were reached to the peak in free swimming larvae before the appearance of higher level of MDA in 7 day starved larvae. The level of MDA was significantly higher in 7 day starved larvae and significantly lower in 14 day starved larvae. $\sum$ PUFA and $\Sigma n-3$ fatty acid have the highest level in 7 day starved larvae and lowest level in 14 day starved larvae. After the free swimming larvae, there was a significant decrease in vitamin $\mathrm{E}$ (a-tocopherol and $\delta$-tocopherol) level in all starved larvae.
\end{abstract}

Keywords: O.mykiss larvae, oxidative stress, starvation, antioxidant enzyme, MDA \& GSH

Öz: Bu çalışmada Oncorhynchus mykiss larvalarının açlıktan sonra oksidatif stres ve antioksidan enzim aktiviteleri çalışılmıştır. Yumurta kesesinin emilimiyle birlikte serbest yüzmeye geçen larvalar 21 gün boyunca aç bırakılmıştır. Balık örnekleri her hafta alınmış ve bütün vücutları, süperoksit dismutaz (SOD), katalaz (CAT), glutatyon peroksidaz (GSHpx), glutatyon redüktaz (GR), glutatyon S-transferaz (GST) analizi ve ayrıca malondialdehit (MDA) ve glutatyon (GSH) analizinde kullanılmışıı. 14 gün aç bırakıımış serbest yüzen yavrularda, analizi yapılan bütün antioksidan enzim aktiviteleri içerisinde, GST ve CAT en yüksek aktiviteye sahipken, SOD and GSHpx en düşük aktiviteye sahip olmuştur. 7 gün aç bırakılan larvalarda MDA'nın yüksek düzeyi ortaya çıkmadan önce SOD aktivitesi serbest yüzen yavrularda zirveye ulaşmıştır. MDA düzeyi 7 gün aç bırakılan larvalarda belirgin olarak daha yüksek ve 14 gün aç bırakılan larvalarda belirgin olarak daha düşük bulunmuştur. $\sum P U F A$ ve $\Sigma n-3$ yağ asidi, 7 gün aç bırakılan larvalarda en yüksek, 14 gün aç bırakılan larvalarda ise en düşük seviyeye sahip olmuştur. Serbest yüzen larvalardan sonra, aç bırakılan larvaların hepsinde E vitamini (a-tokoferol ve $\delta$ - tokoferol) seviyesinde belirgin bir azalma olmuştur.

Anahtar kelimeler: O.mykiss larvaları, oksidatif stress, açlık, antioksidan enzimler, MDA ve GSH 


\section{INTRODUCTION}

The larval stages of fish are considered to be very sensitive periods for the future period and larval quality. Stressful situations (genetic or physical conditions, pollutants and diet) at these sensitive stages can lead to increased disease susceptibility, reduced of survival rate, growth and reproductive success in several fish species or even malformations (Solé et al.,2004). Once the yolk-sac reserves are exhausted, food deprivation or inappropriate food quality may cause a severe reduction in larval survival (Piccinetti et. al., 2014). Food deprivation reduces the energy expenditure and as a consequence the activity, resulting to lower oxygen consumption which can lead to oxidative stress caused by hypoxia (Portner and Farrell, 2008). Under this condition, enhanced reactive oxygen species (ROS) are produced. ROS adversely affect cellular proteins, DNA, and membrane lipids (Silva et al., 2017).Glutathione peroxidase (GSHpx) activityis able to detoxify organic peroxides produced by lipid peroxidation.Glutathione reductase $(\mathrm{GR})$ is required to regenerate reducedglutathione (GSH) from oxidized glutathione (GSSG) and regardedas essential to maintain intracellular GSH redox status. Theantioxidant superoxide dismutase (SOD) catalyses dismutation of ${ }_{2}^{-}$to $\mathrm{H}_{2} \mathrm{O}_{2}$, and the resulting $\mathrm{H}_{2} \mathrm{O}_{2}$ is converted water and oxygenby catalase (CAT) or detoxified by GSHpx activity (Ritola et al.,2002)

There are a number of molecules that function as scavengers of free radicals. These low molecular weight antioxidants, such as reduced glutathione, retinoic acid (vitamin A), tocopherol (vitamin E) and ascorbate (vitamin C), act in conjunction with these enzymatic defenses (Pascual et al., 2003; Valko et al., 2006).However, one of the most abundant and most important molecular antioxidants in cellular cytoplasm is glutathione (GSH). It can react directly with ROS species. The balance between GSH and GSSG can be restored by GR. Levels of total GSH, GSSG and GR activity have all been proposed as biomarkers of oxidative stress in fish (Stephensen et al. 2002).

Rainbow trout Oncorhynchus mykiss, are one of major cultured freshwater species. However, a few study (Furné et al., 2011) is available on the effect of starvation on body composition and enzyme activity in O. mykissafter yolk-sac absorption, especially when the total lipid, HUFA content, lipid peroxidation, antioxidant enzyme activity and vitamin E levels are considered together.The understanding of the early larval antioxidant defenses as well as the oxidative damage and oxidative stress are of primary importance. Therefore, thepresent study investigated effects of starvation in free swimming O. mykiss larvae starved for 21 days after yolk-sac absorption, with special emphasis on the activities of the antioxidant enzymes SOD, CAT, GSHpx, GR, GST as well as lipid peroxidation levels. Basic knowledge of starvation on fatty acids, particularly HUFA, total proteins, MDA as an indication of lipid peroxidation, glutathione and fat soluble vitamins were also provided.

\section{MATERIALS AND METHODS}

Eggs and sperm samples used in the present study were obtained from three females and males aged 4 and 3 years, respectively. Mature O. mykiss were artificially spawned; the eggs were fertilized by conventional procedures and immediately transported to a hatchery. Just after yolk-sac absorption, free-swimming larvae were starved over a period of 21 days. When deaths were seen after $21^{\text {th }}$ day in starved larvae, the trial was ended. All samples of starved larvae were collected as $1 \mathrm{~g}$ of 3 repetitions at free-swimming larvae, at $7^{\text {th }}$, $14^{\text {th }}$ and $21^{\text {st }}$ days. Eggs were fertilized in February. The water temperature was $9.7^{\circ} \mathrm{C}$ during embryogenesis, $10.9^{\circ} \mathrm{C}$ during yolk-sac larvae in March and was $12.1^{\circ} \mathrm{C}$ during starving period in April. $\mathrm{pH}$ and oxygen level of the water varied between 7.4-7.6 and $8.5-8.3 \mathrm{mg} \mathrm{L}^{-1}$ respectively from February to April. Hatching occurred 35 days after the fertilization and the yolk-sacs were completely exhausted 19 days posthatching after the embryonic development. When the O. mykiss larvae finished their endogenousfeeding and the larvae being at their free-swimming stage. Justafter yolk-sac absorption, O. mykiss larvae was starved. When deaths were seen after $21^{\text {th }}$ day, the trial was ended. The samples of starved 0 . mykiss larvae $(3 \times 1 \mathrm{~g})$ were taken at free-swimming larvae after yolk-sac absorption and on days 7, 14 and 21. All samples were frozenin liquid nitrogen and stored at $-80^{\circ} \mathrm{C}$ prior to the preparationof the homogenate. The poolin which the fish were reared had a flow-through water supplyoriginating from an underground natural spring. The water flowrate was 26 L $\min ^{-1}$.

\section{Analytical Methods}

Whole body of starved larvae O. mykiss ( $1 \mathrm{~g} \times 3$ replicates) werehomogenized in ice-cold buffer (20 $\mathrm{mM}$ phosphate buffer pH7.4, $1 \mathrm{mM}$ EDTA and $0.1 \%$ Triton X-100). Homogenates werecentrifuged at 30,000 $\times \mathrm{g}$ for $30 \mathrm{~min}$. After centrifugation, thedebris was removed. The supernatant was collected and frozenat $-80^{\circ} \mathrm{C}$ until analysed. The resultant supernatants were useddirectly for enzyme assays.

Superoxide dismutase (SOD) (EC 1.15.1.1) activity was assayedin terms of its ability to inhibit the oxygendependent oxidationof adrenalin (epinephrine) to 
adenochrome by xanthine oxidaseplus xanthine (Panchenko et al., 1975). The reaction was followedat $480 \mathrm{~nm}$ and one unit of SOD activity is defined as the amountof the enzyme causing 50\% inhibition of the rate of adenochromeproduction at $26{ }^{\circ} \mathrm{C}$. Solutions used in SOD activity measurementwere made fresh daily. The assays were run by adding to thecuvette sequentially $0.05 \mathrm{M}$ potassium phosphate buffer $\mathrm{pH} 7.8 / 0.1 \mathrm{mM}$ EDTA, $100 \mu \mathrm{l}$ adrenaline, $100 \mu \mathrm{l}$ xanthine and $200 \mu$ sample. The reaction was then initiated by adding $20 \mu \mathrm{l}$ xanthineoxidase.

Catalase (CAT) (EC 1.11.1.6) activity was measured by followingthe reduction of hydrogen peroxide $\left(\mathrm{H}_{2} \mathrm{O}_{2}\right)$ at $30{ }^{\circ} \mathrm{C}$ and 240 nmusing the extinction coefficient $0.04 \mathrm{mM}-1 \mathrm{~cm}-1$ (Beers and Sizer,1952). Immediately before assay, a stock solution was prepared.The quartz assay cuvette contained $50 \mu \mathrm{l}$ sample solution in a finalvolume of $250 \mu \mathrm{l}$ containing $67 \mathrm{mM}$ phosphate buffer $\mathrm{pH} 7.0$ and $20 \mathrm{mM} \mathrm{H}_{2} \mathrm{O}_{2}$. One unit of CAT represents the amount of enzymethat decomposes 1 $\mu \mathrm{mol}$ of $\mathrm{H}_{2} \mathrm{O}_{2}$ per minute.

Glutathione peroxidase (GSHpx) (EC 1.11.1.9) was assayedby following the rate of NADPH oxidation at $340 \mathrm{~nm}$ by thecoupled reaction with glutathione reductase (Bell et al., 1985).The GSSG generated by GSHpx was reduced by GR and NADPHoxidation was monitored at $340 \mathrm{~nm}$. The quartz assay cuvettecontaining the reaction mixture which consisted of 50 mMpotassium phosphate buffer $(\mathrm{pH}$ 7.1), 1mMEDTA, 3.6mMreducedglutathione (GSH), 3.6

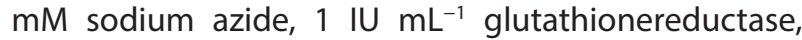
$0.2 \mathrm{mM}$ NADPH and $0.05 \mathrm{mM} \mathrm{H}_{2} \mathrm{O}_{2}$. Moreover,0.05 $\mathrm{mM}$ cumene hydroperoxide was used as substrate instead ofhydrogen peroxide. Sample was added and specific activities weredetermined using the extinction coefficient of $6.22 \mathrm{mM}^{-1} \mathrm{~cm}^{-1}$.

Glutathione reductase (GR) (EC 1.6.4.2) activity was determinedby the oxidation of NADPH at 340 $\mathrm{nm}$ using the extinctioncoefficient $6.22 \mathrm{mM}^{-1} \mathrm{~cm}^{-1}$. Reaction mixture in quartz assaycuvette consisted of $0.1 \mathrm{M}$ potassium phosphate buffer ( $\mathrm{pH}$ 7.2),2 mM EDTA, $0.63 \mathrm{mM}$ NADPH and $0.15 \mathrm{mM}$ GSSG. The reaction was initiated by the addition of the sample.

Glutathione S-transferase (GST) (EC 2, 5, 1, 18) activity wasmeasured at $340 \mathrm{~nm}$ with $1 \mathrm{mM}$ 1-chloro2,4-dinitrobenzene(CDNB) and $1 \mathrm{mM}$ glutathione (GSH) in $100 \mathrm{mM}$ potassiumphosphate buffer, $\mathrm{pH}$ 6.5. The quartz assay cuvette containing $100 \mathrm{mM}$ potassium phosphate buffer pH 6.5. $100 \mathrm{ml} \mathrm{GSH}$ and100 ml CDNB were prepared and the reaction was initiated by theaddition of $50 \mathrm{ml}$ sample. Specific activities were determined usingan extinction coefficient of $9.6 \mathrm{mM}^{-1}$ $\mathrm{cm}^{-1}$.

\section{Fatty Acid Analyses}

Total lipid contents of starvedO. mykiss larvae were extractedafter homogenization in $3: 2(\mathrm{v} / \mathrm{v})$ hexane isopropanol mixturesaccording to procedures described by Hara and Radin (1978). Allsolvents contained $0.01 \%$ butylated hydroxytoluene as an antioxidant.Fatty acid methyl esters were prepared from total lipid by acidcatalyzedtransmethylation at $55{ }^{\circ} \mathrm{C}$ for $15 \mathrm{~h}$ according to methodof Christie (1998). They were analysed in a GC-17A Shimadzu gaschromatograph equipped with SPTM-2380 fused silica capillarycolumn $30 \mathrm{~m} \times 0.25 \mathrm{~mm} \times 0.2$ $\mu \mathrm{m}$ film thickness.The levels of Vitamin $A, D, E, K$ and Cholesterol, Stigmasteroland $\beta$-sitosterol were analysed by Shimadzu full VP series HPLCaccording to the method of Katsanidis and Addis (1999). Totalprotein, glutathione (GSH) and malondialdehyde (MDA) levelswere spectrophotometrically measured. They were assayed at750 $\mathrm{nm}$ according to the method of Lowry et al. (1951) with bovineserum albumin as a standard, $412 \mathrm{~nm}$ according to the method of Teare et al. (1993) and $532 \mathrm{~nm}$ according to the method of Salih et al. (1987) respectively.

\section{Statistical Analysis}

The statistical analyses were performed using a commercialstatistical software (SPSS 15.0) for Windows. All analyticaldeterminationswere performed in triplicate and the mean values (mean \pm S.E) were reported. All data were statistically compared by one wayvariance analysis (ANOVA) and comparisons between means wereperformed with Tukey's test. Differences between means werereported as insignificant if $p>0.05$, significant if $p<0.05$, moresignificant if $p<0.01$ and most significant if $p<0.001$.

\section{RESULTS}

Fatty acid compositions of O. mykissstarved larvae from free-swimmingto 21 days starvedlarvae are

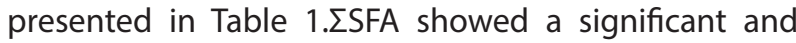
steady increase over the 21-day starving period. It was noted that on the investigation in the fatty acid composition of the free-swimming larvae and 7, 14 and 21 days starved larvae, while C14:0 fatty acidwas not detected in the 21 days starved larvae of O. mykiss, C15:0, C17:0 ve C22:0 fatty acids were not detected from 7 days starved larvae to 21days starved larvae of O. mykiss. SSFA were at a minimum $(26.43 \%)$ at freeswimming larvae and reached a maximum (31.63\%) at 21 day starved larvae of 0 . mykiss. The percentages of the $\Sigma$ SFA increased significantly $(P<0.05)$ at 7,14 and 21 days starved larvae due to increase in the content of the most abundant saturated fatty acid, C16:0 and C18:0. 
Zengin, Ege Journal of Fisheries and Aquatic Sciences, 35(4), 387-396 (2018)

Table 1. Fatty acid composition of free-swimming larvae and 7, 14, and 21 days starved larvae of Oncorhynchus mykiss*

\begin{tabular}{|c|c|c|c|c|}
\hline Fatty acids & $\begin{array}{c}\text { Free-swimming } \\
\text { Larvae }\end{array}$ & $\begin{array}{c}7 \text { day } \\
\text { Starved larvae }\end{array}$ & $\begin{array}{c}14 \text { day } \\
\text { Starved larvae }\end{array}$ & $\begin{array}{c}21 \text { day } \\
\text { Starved larvae }\end{array}$ \\
\hline C14:0 & $1.17 \pm 0.03^{\mathrm{a}}$ & $0.72 \pm 0.01^{b}$ & $0.73 \pm 0.04^{b}$ & $0.00 \pm 0.00^{c}$ \\
\hline C15:0 & $0.20 \pm 0.01^{\mathrm{a}}$ & $0.00 \pm 0.00$ & $0.00 \pm 0.00$ & $0.00 \pm 0.00$ \\
\hline C16:0 & $16.71 \pm 0.06^{\mathrm{a}}$ & $18.73 \pm 0.05^{b}$ & $18.65 \pm 0.11^{b}$ & $19.80 \pm 0.08^{c}$ \\
\hline C17:0 & $0.23 \pm 0.01^{\mathrm{a}}$ & $0.00 \pm 0.00$ & $0.00 \pm 0.00$ & $0.00 \pm 0.00$ \\
\hline C18:0 & $6.93 \pm 0.03^{a}$ & $8.97 \pm 0.04^{b}$ & $10.14 \pm 0.06^{c}$ & $11.17 \pm 0.24^{d}$ \\
\hline C22:0 & $0.43 \pm 0.03^{a}$ & $0.00 \pm 0.00$ & $0.00 \pm 0.00$ & $0.00 \pm 0.00$ \\
\hline C24:0 & $0.75 \pm 0.04^{\mathrm{ac}}$ & $0.40 \pm 0.01^{b}$ & $0.71 \pm 0.02^{\mathrm{cd}}$ & $0.66 \pm 0.00^{d}$ \\
\hline$\Sigma$ SFA & $26.43 \pm 0.11^{\mathrm{a}}$ & $28.82 \pm 0.09^{b}$ & $30.23 \pm 0.10^{c}$ & $31.63 \pm 0.27^{d}$ \\
\hline C16:1n-7 & $2.85 \pm 0.03^{\mathrm{a}}$ & $1.93 \pm 0.05^{b}$ & $2.01 \pm 0.08^{b}$ & $1.94 \pm 0.10^{b}$ \\
\hline $\mathrm{C} 17: 1$ & $0.18 \pm 0.00^{\mathrm{a}}$ & $0.00 \pm 0.00$ & $0.00 \pm 0.00$ & $0.00 \pm 0.00$ \\
\hline C18:1n-9 & $16.38 \pm 0.07^{\mathrm{a}}$ & $13.82 \pm 0.13^{b}$ & $16.55 \pm 0.08^{\mathrm{a}}$ & $14.94 \pm 0.01^{c}$ \\
\hline$C 20: 1 n-9$ & $0.82 \pm 0.02^{\mathrm{a}}$ & $0.39 \pm 0.00^{b}$ & $0.47 \pm 0.01^{c}$ & $0.00 \pm 0.00$ \\
\hline C22:1 & $0.42 \pm 0.02^{\mathrm{a}}$ & $0.00 \pm 0.00$ & $0.00 \pm 0.00$ & $0.00 \pm 0.00$ \\
\hline$\Sigma$ MUFA & $20.66 \pm 0.06^{\mathrm{a}}$ & $16.14 \pm 0.18^{b}$ & $19.03 \pm 0.01^{c}$ & $16.89 \pm 0.09^{d}$ \\
\hline C18:3n-3 & $1.84 \pm 0.04^{\mathrm{a}}$ & $0.98 \pm 0.04^{b}$ & $1.06 \pm 0.03^{b}$ & $0.73 \pm 0.01^{c}$ \\
\hline$C 20: 5 n-3$ & $7.90 \pm 0.06^{\mathrm{a}}$ & $6.43 \pm 0.06^{b}$ & $5.39 \pm 0.10^{c}$ & $5.12 \pm 0.06^{d}$ \\
\hline$C 22: 5 n-3$ & $2.43 \pm 0.05^{\mathrm{a}}$ & $2.96 \pm 0.05^{b}$ & $3.47 \pm 0.12^{c}$ & $1.90 \pm 0.08^{d}$ \\
\hline$C 22: 6 n-3$ & $30.00 \pm 0.06^{\mathrm{a}}$ & $36.27 \pm 0.10^{b}$ & $30.79 \pm 0.21^{c}$ & $34.44 \pm 0.13^{d}$ \\
\hline$\sum n-3$ & $42.17 \pm 0.11^{\mathrm{a}}$ & $46.65 \pm 0.09^{b}$ & $40.70 \pm 0.23^{c}$ & $42.19 \pm 0.09^{\mathrm{a}}$ \\
\hline C18:2n-6 & $5.98 \pm 0.06^{\mathrm{a}}$ & $3.87 \pm 0.10^{b}$ & $5.20 \pm 0.17^{c}$ & $4.41 \pm 0.10^{d}$ \\
\hline C18:3n-6 & $0.23 \pm 0.02^{\mathrm{a}}$ & $0.00 \pm 0.00$ & $0.00 \pm 0.00$ & $0.00 \pm 0.00$ \\
\hline$C 20: 2 n-6$ & $0.78 \pm 0.02^{\mathrm{a}}$ & $0.62 \pm 0.02^{b}$ & $0.69 \pm 0.01^{c}$ & $0.62 \pm 0.01^{b}$ \\
\hline$C 20: 3 n-6$ & $0.60 \pm 0.01^{\mathrm{a}}$ & $0.43 \pm 0.01^{b}$ & $0.60 \pm 0.01^{\mathrm{a}}$ & $0.00 \pm 0.00$ \\
\hline$C 20: 4 n-6$ & $3.15 \pm 0.07^{\mathrm{a}}$ & $3.46 \pm 0.03^{b}$ & $3.54 \pm 0.10^{b}$ & $4.27 \pm 0.02^{c}$ \\
\hline$\Sigma n-6$ & $10.74 \pm 0.04^{a}$ & $8.39 \pm 0.14^{b}$ & $10.03 \pm 0.20^{c}$ & $9.30 \pm 0.09^{d}$ \\
\hline$\Sigma$ PUFA & $52.91 \pm 0.07^{a}$ & $55.04 \pm 0.10^{b}$ & $50.74 \pm 0.11^{c}$ & $51.49 \pm 0.18^{d}$ \\
\hline$\sum n-3 / \sum n-6$ & $3.93 \pm 0.02^{\mathrm{a}}$ & $5.57 \pm 0.10^{b}$ & $4.06 \pm 0.10^{\mathrm{a}}$ & $4.54 \pm 0.03^{c}$ \\
\hline
\end{tabular}

*The data are expressed as percentages of total fatty acids. Each value is the mean \pm S.E. (standard error) of 3 repetitions. Superscripts after values in a same line with different letters represent significant difference $(p<0.05)$. $\Sigma$ : Total. $\Sigma$ SFA: Total Saturated Fatty Acid.

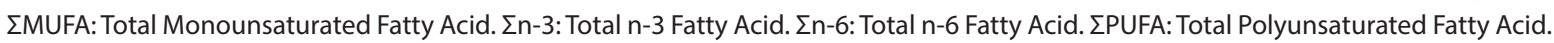

However, in the case of IMUFA, they were at a minimum (16.14\%) at 7 days starved larvae and at a maximum (20.66\%) at free-swimming larvae O. mykiss. The percentages of the $\Sigma$ MUFA increased significantly $(P<0.05)$ at 14 day starved larvae due to increase in the content of the most abundant unsaturated fatty acid, C18:1n-9. According to free-swimming larvae, a statistically significant $(P<0.05)$ decrease in the percentages of $\mathrm{C} 16: 1 \mathrm{n}-7$ was observed at 7, 14 and 21 days starved larvae.Throughout the starving periods, total polyunsaturated fatty acids ( $\Sigma$ PUFA) were at a maximum (55.04\%) at 7 days starved larvae and at a minimum (50.74\%) at 14 days starved larvae of $O$. mykiss, mainly composed of the increased percentage of C18:2n-6, C20:4n-6(ARA) C20:5n-3, C22:5n-3 and C22:6n-3. 
Table 2. Changes in Total Protein, GSH and MDA levels in free-swimming larvae and 7, 14, and 21 days starved larvae of Oncorhynchus mykiss*

\begin{tabular}{|c|c|c|c|c|}
\hline & $\begin{array}{c}\text { Free-swimming } \\
\text { Larvae }\end{array}$ & $\begin{array}{c}7 \text { day } \\
\text { Starved larvae }\end{array}$ & $\begin{array}{c}14 \text { day } \\
\text { Starved larvae }\end{array}$ & $\begin{array}{c}21 \text { day } \\
\text { Starved larvae }\end{array}$ \\
\hline Total Protein mg/g & $49,67 \pm 0,86^{b c}$ & $51,42 \pm 0,98^{b}$ & $52,55 \pm 1,10^{\mathrm{b}}$ & $47,25 \pm 0,70^{c}$ \\
\hline $\mathrm{GSH} \mu \mathrm{mol} / \mathrm{g}$ & $0,86 \pm 0,04^{a}$ & $0,51 \pm 0,02^{d}$ & $0,53 \pm 0,00^{d}$ & $0,85 \pm 0,01^{\mathrm{a}}$ \\
\hline MDA nmol/g & $17,08 \pm 1,16^{a}$ & $30,78 \pm 1,06^{d}$ & $14,59 \pm 0,41^{a}$ & $16,56 \pm 0,38^{a}$ \\
\hline
\end{tabular}

*Each value is the mean \pm S.E. (standard error) of 3 repetitions. Superscripts after values in a same line with different letters represent significant difference.

a: Values ofp $>0.05$ is not statistically significant.

c: Values of $p<0.01$ is statistically more significant b: Values of $p<0.05$ is statistically significant.

$d$ : Values of $p<0.001$ is statistically most significant
The level of total protein, glutathione (GSH) and malondialdehyde (MDA) in mg per gram tissue, $\mu$ mol per gram tissue and nmol per gram tissue respectively were examined in fish 0 . mykiss throughout the period of 21 days starving (Table 2).Compared with the $O$. mykiss larvae passing through the free swimming stages with the absorption of the yolk-sac, it was observed that no significant change ( $p>0.05)$ had occurred in the total protein amounts of 7, 14 and 21days starved larvae. The decrease in the total protein amounts of the larvae starved for 21 days was significant $(p<0.01)$ than that of the 7 days and 14 days starved larvae. The difference in the GSH concentration between the free swimming larvae and 21 days starved larvae was found statistically insignificant $(P>0.05)$. However the GSH concentration in7 and 14 days starved larvae exhibited significantly $(\mathrm{P}<0.001)$ low values. While the GSH concentration in 7 and 14 days starved larvae exhibited significantly $(P<0.001)$ low values, the most significant increase in the MDA concentration was detected in 7 days starved larvae. There was no significant $(P>0.05)$ change in the MDA concentration of starved larvae at the other stages of the starving period.

Table 3. Changes in antioxidant enzymes, superoxide dismutase (SOD), catalase (CAT), glutathione peroxidase (GSHpx), glutathione reductase (GR) and glutathione S-transferase (GST) activities in free-swimming larvae and 7, 14, and 21 days starved larvae of Oncorhynchus mykiss*

\begin{tabular}{lrcccc}
\hline & & $\begin{array}{c}\text { Free-swimming } \\
\text { Larvae }\end{array}$ & $\begin{array}{c}7 \text { day } \\
\text { Starved larvae }\end{array}$ & $\begin{array}{c}14 \text { day } \\
\text { Starved larvae }\end{array}$ & $\begin{array}{c}21 \text { day } \\
\text { Starved larvae }\end{array}$ \\
\hline SOD & $(\mathrm{U} / \mathrm{g})$ & $8,77 \pm 0,67$ & $6,90 \pm 0,03$ & $5,66 \pm 0,24^{\mathrm{d}}$ & $6,15 \pm 0,14^{\mathrm{c}}$ \\
CAT & $(\mu \mathrm{g} / \mathrm{g} / 1 \mathrm{~min})$ & $140,12 \pm 4,12$ & $126,44 \pm 2,46$ & $302,12 \pm 3,12^{\mathrm{d}}$ & $206,82 \pm 1,71^{\mathrm{d}}$ \\
$\mathrm{GSHpx}$ & $(\mathrm{U} / \mathrm{g} / 1 \mathrm{~min})$ & $87,16 \pm 1,21$ & $80,12 \pm 0,97^{\mathrm{a}}$ & $65,62 \pm 2,51^{\mathrm{c}}$ & $75,86 \pm 2,79^{\mathrm{a}}$ \\
GR & $(\mathrm{U} / \mathrm{g} / 1 \mathrm{~min})$ & $30,43 \pm 3,76$ & $27,81 \pm 3,62^{\mathrm{a}}$ & $33,33 \pm 2,09^{\mathrm{a}}$ & $39,79 \pm 0,43^{\mathrm{c}}$ \\
GST & $(\mu \mathrm{g} / \mathrm{g} / 1 \mathrm{~min})$ & $250,33 \pm 6,25$ & $243,67 \pm 4,72$ & $279,33 \pm 3,48^{\mathrm{c}}$ & $168.00 \pm 5,77^{\mathrm{d}}$ \\
\hline
\end{tabular}

*The meaning of the symbols is given under Table 2 .

The specific activities of five enzymes of the antioxidation system in starved larvae of O. mykiss over a period of 21 days starving are shown in Table 3. SOD activity in free swimming larvaeand 7 days starved larvae showed its highest valuebut it its lowest value occurred in the 14 day starved larvae. Conversely, CAT activity was significantly $(P<0.001)$ low in free swimming larvae and 7 days starved larvae and significantly $(P<0.001)$ high in 14 and 21 days starved larvae. Compared to free swimming larvae, GSHpxactivity showed a significant $(\mathrm{P}<0.01)$ decrease in 14 days starved larvae which had the lowest activity in all starved larvae. Its activity did not showany significant change in 7 and 21 daysstarved larvae $(P>0.05)$. GR activity did notshow any significant change from free swimming larvae to 14 days starved larvae which had the lowest activity but it its highest 
value occurred in the 21 days starved larvae $(P<0.01)$. Unlike SODactivity which showed its highest value in the first two weeks, GSTactivity showed its highest value in third weeks, but it decreased sharply in 21 days starved larvae $(P<0.001)$.

Table 4 shows the levels of Retinol $(\mu \mathrm{g} / \mathrm{g})$, Vitamin $D_{3}(\mu \mathrm{g} / \mathrm{g})$, $\delta$-Tocopherol $(\mu \mathrm{g} / \mathrm{g})$, a-Tocopherol $(\mu \mathrm{g} / \mathrm{g})$, Vitamin $K_{1}(\mu \mathrm{g} / \mathrm{g})$, Vitamin $K_{2}(\mu \mathrm{g} / \mathrm{g})$, Cholesterol $(\mu \mathrm{mol} / \mathrm{g})$, Stigmasterol $(\mu \mathrm{g} / \mathrm{g})$ and $\beta$-sitosterol $(\mu \mathrm{g} / \mathrm{g})$ in free swimming larvae, 7, 14 and 21 days starved O. mykiss larvae.When retinol levels were examined throughout the period of 21 days starving, there were the most significant $(\mathrm{P}<0.001)$ decrease in all starved larvae according to the free swimming larvae.Therewere no significant differences in the level of vitamin $D_{3}$ between the free swimming larvae, 14 days starved larvae and 21 days starved larvae, but the most significant $(p<0.001)$ increase was observed in the 7 days starved larvae. $\delta$-Tocopherol level showed a significant $(P<0.01)$ decrease in 7 days starved larvae before decreasing sharply in 14 days and 21 days starved larvae $(P<0,001)$. The highest $\delta$-tocopherol level was observed in free swimming larvae.a-tocopherol did notshow any marked change during the 21 days starving period. The highest a-tocopherol values $(25,47 \pm 0,18)$ were found in the free swimming larvae, but it its lowest value $(11,49 \pm 0,22)$ occurred in the 21 days starved larvae.O. mykiss's starved larvae did not show any remarkablechange in vitamin $\mathrm{K}_{1}$ levels from 7 days to 21 days starved larvae, butthe level of $\mathrm{K}_{1}$ was most significantly $(\mathrm{P}<0.001)$ higher in free swimming larvae.In the starving period of O.mykiss's larvae, $\mathrm{K}_{2}$ levels showed asignificant $(\mathrm{P}<0.01)$ decrease in 7 days starved larvae and the most significant $(P<0.001)$ decrease in 14 and 21 days starved larvae. $\mathrm{K}_{2}$ levels was high in the free swimming larvae and significantly $(P<$ 0.001 ) was low in 14 days starved larvae and 21 days starved larvae.

Table 4. Changes in Retinol, Vitamin $\mathrm{D}_{3^{\prime}} \delta$-Tocopherol , $\mathrm{a}$-Tocopherol , Vitamin $\mathrm{K}_{1}$, Vitamin $\mathrm{K}_{2^{\prime}}$ Cholesterol, Stigmasterol and $\beta$-sitosterol levels in free-swimming larvae and 7, 14, and 21 days starved larvae of Oncorhynchus mykiss ${ }^{*}$

\begin{tabular}{|c|c|c|c|c|}
\hline & $\begin{array}{l}\text { Free-swimming } \\
\text { Larvae }\end{array}$ & $\begin{array}{c}7 \text { day } \\
\text { Starved larvae }\end{array}$ & $\begin{array}{c}14 \text { day } \\
\text { Starved larvae }\end{array}$ & $\begin{array}{c}21 \text { day } \\
\text { Starved larvae }\end{array}$ \\
\hline $\begin{array}{l}\text { Retinol (vit. A) } \\
\\
\mu \mathrm{g} / \mathrm{g}\end{array}$ & $0,56 \pm 0,05$ & $0,27 \pm 0,04^{d}$ & $0,24 \pm 0,03^{d}$ & $0,24 \pm 0,04^{d}$ \\
\hline Vitamin $D_{3}$ & $0,11 \pm 0,02^{\mathrm{a}}$ & $0,25 \pm 0,02^{d}$ & $0,07 \pm 0,00^{\mathrm{a}}$ & $0,06 \pm 0,01^{\mathrm{a}}$ \\
\hline$\delta$-Tocopherol & $2,04 \pm 0,19$ & $1,38 \pm 0,15^{c}$ & $0,55 \pm 0,08^{d}$ & $0,27 \pm 0,04^{d}$ \\
\hline a-Tocopherol & $25,47 \pm 0,18$ & $13,98 \pm 0,18^{d}$ & $15,53 \pm 0,29^{d}$ & $11,49 \pm 0,22^{d}$ \\
\hline Vitamin $\mathrm{K}_{1}$ & $0,31 \pm 0,01$ & $0,13 \pm 0,00^{d}$ & $0,07 \pm 0,00^{d}$ & $0,09 \pm 0,01^{d}$ \\
\hline Vitamin $\mathrm{K}_{2}$ & $4,07 \pm 0,10$ & $2,56 \pm 0,18^{c}$ & $1,71 \pm 0,19^{d}$ & $0,71 \pm 0,04^{d}$ \\
\hline $\begin{array}{l}\text { Cholesterol } \\
\qquad \mu \mathrm{mol} / \mathrm{g}\end{array}$ & $3,22 \pm 0,06$ & $2,51 \pm 0,04^{c}$ & $2,48 \pm 0,24^{c}$ & $2,73 \pm 0,11^{b}$ \\
\hline $\begin{array}{l}\text { Stigmasterol } \\
\mu \mathrm{g} / \mathrm{g}\end{array}$ & $94,13 \pm 3,35$ & $82,93 \pm 1,97^{b}$ & $65,80 \pm 1,26^{d}$ & $56,62 \pm 4,90^{d}$ \\
\hline$\beta$-sitosterol & $0,22 \pm 0,02^{\mathrm{a}}$ & $0,22 \pm 0,04^{a}$ & $0,24 \pm 0,04^{a}$ & $0,26 \pm 0,00^{\mathrm{a}}$ \\
\hline
\end{tabular}

*The meaning of the symbols is given under Table 2 .

Cholesterol levels showed a small but statistically significant $(P<0.05)$ decrease in 21 days starved 0 . mykiss's larvae and the more significant $(\mathrm{P}<0.01)$ decrease in 7 and 14 days starved larvae according to the free swimming larvae. Although therewere no significant differences in stigmasterol levels from 14 days to 21 days starved larvae, the most significant ( $P$ $<0.001)$ decrease was observedin the last two weeks according to the free swimming larvae. $\beta$-sitosterol levels did not show any significant change in any of the groups.

\section{DISCUSSION}

Starvation is a threat that fish often face in their native aquatic ecosystems, which affects their reproduction, development, growth and survival. During starvation, fish goes into a special anti-stress 
status due to the lack of available energy. Specifically, all physiological metabolism in fish undergo a variety of changes, including those relevant to enzymatic activity, energy substance composition, ammonia excretion rate, and many others (Pérez-Jiménez et al. 2007). Lipids are essential molecules of the cell acting as structural components of cell membranes, cellular communication and energy store. These key functions are especially relevant in early developmental stages of teleosts since they exhibit high growth rates demanding significant amounts of lipids as a main source of energy and for membrane formation (RomanPadilla et al., 2016).

Levels of protein in the all starved stages were not significantly affected by starvation. Even though the difference in the protein content was insignificant, an increment was detected for the 7 days and 14 days starved larvae. Results from the present study showed that starvation stimulates protein synthesis in early life stages of the 0 . mykiss larvae. The results implied a likely correlation between starvation and protein synthesis, which is valuable for investigation. This studyhave similar resultwith theseveral studies reported in fingerlings (Labeo rohita) (Yengkokpam et al., 2008),Dicentrarchus labrax (Antonopoulou et al., 2013) and Solea senegalensis during early larval stages (Solé et al., 2004).

The protein and lipid levels of starving larvae are different. In the former case like Salem et al. 2007, the observed increase in protein level with time may be the preservation of the protein synthesis in the growing organism, whereas in the latter it reflects the utilization of the body's lipid reserves mainly due to the utilization of energy derived from lipids during starvation.This results revealed that decrease in protein level occurred after 21 days starvation in 0 . mykiss. This finding was compatible with the study of Salem et al. (2007). They showed that decreased expression of proteins at mRNA level occurred after 21 days starvation in rainbow trout, and mobilize their endogenous reserves to obtain the energy required to maintain vital processes (brain function, respiration, regulation of mineral balance, etc.). Changes in the amount of fatty acids in starved $O$. mykiss larvae were also noticeable (Table 1). In starved O. mykiss larvae, a significant reduction of lipid content occurred from day 7 and kept low levels to day 14 compared to the free swimming larvae and 21 days starved larvae. The amount of $\Sigma$ PUFA in 7 days starved larvae (55.04\%) decreases significantly in 14 days starved larvae (50.74\%) during 7 days of starvation, while total protein increases from 7 days starved larvae $(51.42 \mathrm{mg} / \mathrm{g})$ to 14 days starved larvae $(52.55 \mathrm{mg} / \mathrm{g})$ even if no significant differences were observed among
(Tables 1 and 2). Lipid peroxidation, specifically PUFA oxidation is highly deleterious, resulting in damage to cellular biomembranes as a consequence of oxidative deterioration of membrane lipids (Porter et al., 1995).

The intensive use of C18:1n-9 and C16:1n-7 during development was observed in 7 and 21 days starved larvae. The intense utilization of monounsaturated fatty acids, especially C18:1n-9 and C $16: 1 n-7$ pointing out the importance of these nutrients as energy substrates (Abi-ayad et al., 2004). There was, even, an increase of saturated fatty acids especially C16:0 and C18:0, probably due to bioconversion processes which is in accordance with other studies (Cejas et al., 2004; Abi-ayad et al., 2004). On examination of n-6 and $n-3$ fatty acids, it was determined that the starved larvae, in comparison with the fed larvae (Zengin and Yilmaz., 2016), while using less C20:5n-3, they more strongly conserved C22:6n-3. This supports the view that C20:5n-3 and C22:6n-3 acids are generally spared for physiological functions as well for incorporation in specific tissues such as the brain and retina. During starvation C22:6n-3 was preferentially conserved compared with C20:5n-3 (Oxley et al., 2005).

Although the starved 0 . mykiss were under very difficult nutritional conditions, Arachidonic acid (C20:4n-6) acids were more strongly conserved in the starved larvae than in the fed larvae (Zengin and Yilmaz., 2016).C20:4n-6and C20:5n-3 exhibit a competitive relationship for binding to some enzymes in fish, such as the eicosanoid synthesis enzymes, phospholipid esterase or fatty acid elongase (Tocher, 2003). C20:4n-6 is the preferred substrate for eicosanoids, whereas $\mathrm{C} 20: 5 \mathrm{n}-3$ is the preferred substrate for phosphoglycerides. But the amount of the C20:4n-6 significantly inreased with the increasing starvation period. In starved larvae, there was an apparent preference in utilization of $\mathrm{C} 20: 5 n-3$ than C20:4n-6. Investigations have been carried out on the physiological effects of C20:4n-6. C20:4n-6, which is precursor of eicosanoids, has an importance on the growth and reproduction of fish and also many physiological events, such as gamet, larvae quality, fertilization of eggs and hatching, survival rate of hatched larvae, immune system, and adaptation to changeable environmental factors (i.e., changes in salinity levels of water) (Bae et al., 2010; Harlığlu, 2014).

Changes on the levels of certain metabolites, such as MDA and GSH, and on the activity of some antioxidant enzymes such as SOD, CAT, GSHpx, GR and GST have been described as biomarkers of oxidative stress provoked either by different nutritional conditions or by prolonged starvation (Pascual et al., 2003; Morales et al., 2004). Because of the high unsaturation, C20:4n-6 and 
C20:5n-3are easy to be attacked by free radicals, which cause lipid peroxidation and impair the functional integrity of cell membranes and enzyme activity. MDA is the end product of lipid peroxidation and its content could reflect the degree of lipid peroxidation. It is an important indicator of the oxidative changes of lipid (Tian et al., 2017). Results from the present study showed that during 21 days of starvation, the highest MDA generation was enhanced in 7 days starved larvae that antioxidant defenses were inadequate for effective scavenging ROS, and leading to the appearance of lipid peroxidation as a MDA generation. Thus, the highest MDA content resulted in decreased levels of total PUFA, particularly eicosapentaenoic acid $(C 20: 5 n-3)$ in 14 and 21 days starved larvae. Based on MDA levels, this results clearly showed that prolonged starvation led to oxidative stress, with starved $O$. mykiss larvae showing increase in MDA with respect to the free swimming larvae. A study with sea bream (Sparus aurata) evaluated the influence of prolonged starvation on MDA levels, and a significant increase of this metabolite has been reported (Pascual et al., 2003).

Among the antioxidant nutrients, vitamin $\mathrm{E}$ is the major membrane-bound lipid-soluble antioxidant. In the present study, there is the most significant decrease in vitamin $E$ (a-tocopherol and $\delta$-tocopherol) level in all starved larvae of $O$. mykiss according to the free swimming larvae. These results indicated that vitamin E deficiency impaired the antioxidant capacity in the starved larvae. The intracellular levels of nonenzymatic antioxidants, GSH influence the activity of the enzymatic antioxidants. As shown in Table 2 and 4, decreased in GSH content and the vitamin E levels were not protect $O$. mykiss larvae against lipid peroxidation. Decrease in vitamin E level significantly decreased the GSH content in the 7 and 14 days starved larvae. Decrease in vitamin E level also significantly decreased the activities of SOD and GSHpx in 14 days starved larvae (Morales et al., 2004; Pan et al., 2017). Thus, Vitamin $E$ is an indispensable nutrient required to maintain normal physiological functions in fish and has been used in fish diets as an antioxidant substance to prevent the peroxidation of highly unsaturated fatty acids (HUFA) in fish oil (Ortuño et al., 2000).In order to evaluate the effects of starvation as a source of oxidative stress, we checked the GSH levelsin the 21 days starving period(Table 2 ). In the present study we have detected GSH depletion in O. mykiss larvae and the decline in GSH levels occured in 7 days to 14 days starvation. The starved fish had low GSH levels. These changes were coincident with the appearance of MDA shown as useful early biomarkers of oxidative stress. Results from Pascual et al. (2003) confirm this conclusion.

GSH acts as an effective antioxidant molecule besides serving as a substrate for GSHpx and GR to neutralize $\mathrm{H}_{2} \mathrm{O}_{2}$ produced by SOD. Thus, cellular GSH store represents the competency of living organism to resist the oxidative damage. GSHpx catalyses a variety of lipid peroxides by using GSH. In general, GSH is reformed by GR in a NADPH dependent reaction, and $\mathrm{NADPH}$ is generated by multiple redox enzymatic reactions that are markedly synchronized with nutrient supply (Morales et al., 2004; Sinha et al., 2015).Lower availability of NADPH as a consequence of nutrient limitation would curtail GR activity. This was reflected by an impaired GR activity in starved fish accompanied by a decline in recycling rate of GSH regeneration. Thisindicate an insufficient GSH-recycling system in starved fish under starvation conditions. Similarly, depletion of endogenous GSH pool in fish has been reported to occur under a situation of starvation (Sinha et al., 2015).

While the activities of GSHpx are reduced in 14 days starved larvae during starvation, GR activity showed the highest value when deaths were seen at $21^{\text {th }}$ day. GR activities increased in parallel with starvation. A similar increase in the hepatic GR activity was reported in Sparus aurata (Pascual et al., 2003). The nutritional deficiency that fish were confronted to, could have restricted the availability of sulphur amino acids. This might detain the production of GSH and functional activities of GSHpx in the starved fish. (Paterson et al., 2001). In this study, starvation condition have shown that starvation was resulted in the most significant decrease in GSH content in 7 days and 14 days starved O. mykiss larvae, connoting an disadvantage for the starved larvae to resist oxidative stress.

Glutathione S-transferases have a critical role against oxidative damage (Elia et al., 2003). GST may be increased, especially in diets with low vitamin $E$, as it is thought to form GSH conjugates with peroxy radicals (Choi et al., 2008). Thus, GST can inactivate lipoperoxidation products, lipid hydroperoxides, and their derivatives (Doyen et al., 2008).Unlike Mourente et al. (1999) and Pascual et al. (2003), GST activity in this study showed the most significant increase in 14 days starved 0 . mykiss larvae. We observed that from free swimming larvae, all enzymatic activities were already measurable and they tended to increase in the case of CAT, GR, GST and to decrease in the case of SOD and GSHpx in 21 days starvation periods.The highest CAT and GST activities during starvation suggest that defences against ROS assume greater importance during periods of starvation (Guderley et al., 2003). In response to the starvation, 0 . mykiss larvae showed the 
lowest activities of SOD and GSHpx of any other animal in previous studies (Morales et al., 2004).

In conclusion, various metabolic adjustments were observed during 21 days starvation in O. mykiss larvae. Lipids played a more important role as energy reserves on a relative basis in whole body; lipids were more important sources of catabolizable energy in starved larvae, whereas protein might be preferentially mobilized in muscle. O. mykiss larvae preferentially utilized C18:1n-9 and C16:1n-7 as energy substrate and preferentially reserved $\mathrm{C} 16: 0$ and $\mathrm{C} 18: 0$ during starvation. MUFA were a major energy source for starving O. mykiss larvae, and DHA and EPA in O. mykiss larvae during starvation were conserved. The amount of protein during starvation may reflect its abundance in the larval body, their protection by intracellular chaperones or their critical functional roles. GR activity

\section{REFERENCES}

Abi-Ayad, S., Boutiba, Z., Mélard, C., \& Kestemont, P. (2004). Dynamics of Total Body Fatty Acids During Early Ontogeny of Pikeperch (Sander lucioperca) Larvae. Fish Physiology and Biochemistry, 30(2)، 129-136. DOI: 10.1007/s10695-005-3417-9

Antonopoulou, E., Kentepozidou, E., Feidantsis, K., Roufidou, C., Despoti, S., \& Chatzifotis, S. (2013). Starvation and re-feeding affect Hsp expression, MAPK activation and antioxidant enzymes activity of European Sea Bass (Dicentrarchus labrax). Comparative Biochemistry and Physiology Part A: Molecular \& Integrative Physiology, 165(1), 79-88. DOI: 10.1016/j.cbpa.2013.02.019

Bae, J., Kim, D., Yoo, K., Kim, S., Lee, J., \& Bai, S. C. (2010). Effects of Dietary Arachidonic Acid (20:4n-6) Levels on Growth Performance and Fatty Acid Composition of Juvenile Eel, Anguilla japonica. Asian-Australasian Journal of Animal Sciences, 23(4), 508-514. DOI: 10.5713/ajas.2010.90491

Beers, R.F., Sizer, I.W. (1952). Spectrophotometric method for measuring the breakdown of hydrogen peroxide by catalase. The Journal of Biological Chemistry, 195, 133-140. PMID: 14938361

Bell, J. G., Cowey, C. B., Adron, J. W., \& Shanks, A. M. (1985). Some effects of vitamin $\mathrm{E}$ and selenium deprivation on tissue enzyme levels and indices of tissue peroxidation in rainbow trout (Salmo gairdneri). British Journal of Nutrition, 53(01), 149-157. DOI: 10.1079/bjn19850019

Cejas, J. R., Almansa, E., Jérez, S., Bolaños, A., Felipe, B., \& Lorenzo, A. (2004). Changes in lipid class and fatty acid composition during development in white seabream (Diplodus sargus) eggs and larvae. Comparative Biochemistry and Physiology Part B: Biochemistry and Molecular Biology, 139(2), 209-216. DOI: 10.1016/j.cbpc.2004.07.010

Choi, C. Y., An, K. W., \& An, M. I. (2008). Molecular characterization and mRNA expression of glutathione peroxidase and glutathione S-transferase during osmotic stress in olive flounder (Paralichthys olivaceus). Comparative Biochemistry and Physiology Part A: Molecular \& Integrative Physiology, 149(3), 330-337. DOI: 10.1016/j.cbpa.2008.01.013

Christie, W. W. (1998). Gas chromatography-mass spectrometry methods for structural analysis of fatty acids. Lipids, 33(4), 343353. DOI: $10.1007 / \mathrm{s} 11745-998-0214-\mathrm{X}$

Doyen, P., Bigot, A., Vasseur, P., \& Rodius, F. (2008). Molecular cloning increased in parallel with starvation, matching this results in the 21-day period. GSHpx and GST play important roles in detoxification of ROS. The increase in GST activity during the experimental period suggests the detoxification of toxic products of lipid peroxidation, such as MDA (Elia et al., 2003). Inthis study, the lowest level of GST in 21 days starved larvae was resulted in a significant reduction of $O$. mykiss larval capacity to with stand oxidative stress following 21 days of starvation. Clearly, starvation or species nutritional deficiencies can weaken anti-oxidant protections.

\section{ACKNOWLEDGEMENTS}

This work was funded by the Research Fund of CUMHURIYET UNIVERSITY (Number: EĞT-036) (SIVAS, TURKEY). We thank the local and commercial Fish Farm in Zara (Sivas) for providing theeggs and sperm samples.

and expression study of pi-class glutathione S-transferase (pi-GST) and selenium-dependent glutathione peroxidase (Se-GPx) transcripts in the freshwater bivalve Dreissena polymorpha. Comparative Biochemistry and Physiology Part C: Toxicology \& Pharmacology, 147(1), 69-77.

DOI: 10.1016/j.cbpc.2007.08.002

Elia, A. C., Galarini, R., Taticchi, M. I., Dörr, A. J., \& Mantilacci, L. (2003). Antioxidant responses and bioaccumulation in Ictalurus melas under mercury exposure. Ecotoxicology and Environmental Safety, 55(2), 162-167. DOI: 10.1016/s0147-6513(02)00123-9

Furné, M., Morales, A. E., Trenzado, C. E., García-Gallego, M., Carmen Hidalgo, M., Domezain, A., \& Sanz Rus, A. (2011). The metabolic effects of prolonged starvation and refeeding in sturgeon and rainbow trout. Journal of Comparative Physiology B, 182(1), 63-76. DOI: 10.1007/s00360-011-0596-9

Guderley, H., Lapointe, D., Bédard, M., \& Dutil, J. (2003). Metabolic priorities during starvation: enzyme sparing in liver and white muscle of Atlantic cod, Gadus morhua L. Comparative Biochemistry and Physiology Part A: Molecular \& Integrative Physiology, 135(2),347-356. DOI:10.1016/s1095-6433(03)00089-8

Hara, A., \& Radin, N. S. (1978). Lipid extraction of tissues with a low-toxicity solvent. Analytical Biochemistry, 90(1), 420-426. DOI: 10.1016/0003-2697(78)90046-5

Harlığlu, A. (2014). Araşidonik Asidin Balık Beslemesinde Önemi (The Importance of Arachidonic Acid in Fish Nutrition.) Yunus Araştırma Bülteni, 2014(3). DOI: 10.17693/yunusae.v2014i21953.235716

Katsanidis, E., \& Addis, P. B. (1999). Novel HPLC analysis of tocopherols, tocotrienols, and cholesterol in tissue. Free Radical Biology and Medicine, 27(11-12), 1137-1140.

DOI: 10.1016/s0891-5849(99)00205-1

Lowry, O.H., Rosebrough, N.J., Farr, A.L., Randall, R.J., (1951). Protein measurement with the folin phenol reagent. The Journal of Biological Chemistry 193(1), 265-275. PMID:14907713

Morales, A. E., Pérez-Jiménez, A., Carmen Hidalgo, M., Abellán, E., \& Cardenete, G. (2004). Oxidative stress and antioxidant defenses after prolonged starvation in Dentex dentex liver. Comparative Biochemistry and Physiology Part C: Toxicology \& Pharmacology, 139(1-3), 153-161. DOI: 10.1016/j.cca.2004.10.008 
Mourente, G., Tocher, D. R., Diaz, E., Grau, A., \& Pastor, E. (1999). Relationshipsbetweenantioxidants, antioxidantenzymeactivities and lipid peroxidation products during early development in Dentex dentex eggs and larvae. Aquaculture, 179(1-4), 309-324. DOI: 10.1016/s0044-8486(99)00167-2

Ortuño, J., Esteban, M., \& Meseguer, J. (2000). High dietary intake of a-tocopherol acetate enhances the non-specific immune response of gilthead seabream (Sparus aurata L.). Fish \& Shellfish Immunology, 10(4), 293-307. DOI: 10.1006/fsim.1999.0238

Oxley, A., Tocher, D. R., Torstensen, B. E., \& Olsen, R. E. (2005). Fatty acid utilisation and metabolism in caecal enterocytes of rainbow trout (Oncorhynchus mykiss) fed dietary fish or copepod oil. Biochimica et Biophysica Acta (BBA) - Molecular and Cell Biology of Lipids, 1737(2-3), 119-129. DOI: 10.1016/j.bbalip.2005.09.008

Pan, J., Feng, L., Jiang, W., Wu, P., Kuang, S., Tang, L., Tang, W.N., Zhang Y.A., Zhou, X.Q., Liu, Y. (2017). Vitamin E deficiency depressed fish growth, disease resistance, and the immunity and structural integrity of immune organs in grass carp (Ctenopharyngodon idella ): Referring to NF-KB, TOR and Nrf2 signaling. Fish \& Shellfish Immunology, 60, 219-236. DOI: 10.1016/j.fsi.2016.11.044

Panchenko, L. F., Brusov, O. S., Gerasimov, A. M., \& Loktaeva, T. D. (1975). Intramitochondrial localization and release of rat liver superoxide dismutase. FEBS Letters, 55(1-2), 84-87. DOI: 10.1016/0014-5793(75)80964-1

Pascual, P., Pedrajas, J., Toribio, F., López-Barea, J., \& Peinado, J. (2003) Effect of food deprivation on oxidative stress biomarkers in fish (Sparus aurata). Chemico-Biological Interactions, 145(2), 191-199. DOI: 10.1016/s0009-2797(03)00002-4

Paterson, P. G., Lyon, A. W., Kamencic, H., Andersen, L. B., \& Juurlink, B. H. (2001). Sulfur Amino Acid Deficiency Depresses Brain Glutathione Concentration. Nutritional Neuroscience, 4(3), 213-222. DOI: 10.1080/1028415x.2001.11747364

Pérez-Jiménez, A., Guedes, M. J., Morales, A. E., \& OlivaTeles, A. (2007). Metabolic responses to short starvation and refeeding in Dicentrarchus labrax. Effect of dietary composition. Aquaculture, 265(1-4), 325-335. DOI: 10.1016/j. aquaculture.2007.01.021

Piccinetti, C. C., Donati, M., Radaelli, G., Caporale, G., Mosconi, G., Palermo, F., Cossignani, L., Salvatori, R., Lopez, R.P. \& Olivotto, I. (2014). The effects of starving and feeding on Dover sole (Solea solea, Soleidae, Linnaeus, 1758) stress response and early larval development. Aquaculture Research, 46(10), 2512-2526. DOI: 10.1111/are.12410

Porter, N. A., Caldwell, S. E., \& Mills, K. A. (1995). Mechanisms of free radical oxidation of unsaturated lipids. Lipids, 30(4), 277-290. DOI: $10.1007 /$ bf02536034

Portner, H. O., \& Farrell, A. P. (2008). Ecology: Physiology and Climate Change. Science, 322(5902), 690-692. DOI: 10.1126/ science.1163156

Ritola, O., Peters, L. D., Livingstone, D. R., \& Lindstrom-Seppa, P. (2002). Effects of in vitro exposure to ozone and/or hyperoxia on superoxide dismutase, catalase, glutathione and lipid peroxidation in red blood cells and plasma of rainbow trout, Oncorhynchus mykiss (Walbaum). Aquaculture Research, 33(3), 165-175. DOI: 10.1046/j.1365-2109.2002.00649.x

Roman-Padilla, J., Rodríguez-Rua, A., Claros, M., Hachero-Cruzado, I., \& Manchado, M. (2016). Genomic characterization and expression analysis of four apolipoprotein A-IV paralogs in Senegalese sole (Solea senegalensis Kaup). Comparative Biochemistry and Physiology Part B: Biochemistry and Molecular Biology, 191, 84-98.
DOI: 10.1016/j.cbpb.2015.09.010

Salem, M., Silverstein, J., Rexroad, C. E., \& Yao, J. (2007). Effect of starvation on global gene expression and proteolysis in rainbow trout (Oncorhynchus mykiss). BMC Genomics, 8(1), 328. DOI: 10.1186/1471-2164-8-328

Salih, A. M., Smith, D. M., Price, J. F., \& Dawson, L. E. (1987). Modified Extraction 2-Thiobarbituric Acid Method for Measuring Lipid Oxidation in Poultry. Poultry Science, 66(9), 1483-1488. DOI: 10.3382/ps.0661483

Silva, T. V., Barbas, L. A., Torres, M. F., Sampaio, L. A., \& Monserrat, J. M. (2017). Lipid peroxidation and antioxidant capacity in Peckoltia oligospila (Günther, 1864) submitted to transport under different concentration of dissolved oxygen. Aquaculture, 481, 72-78. DOI: 10.1016/j.aquaculture.2017.08.024

Sinha, A. K., AbdElgawad, H., Zinta, G., Dasan, A. F., Rasoloniriana, R., Asard, H., Blust, R., \& De Boeck, G. (2015). Nutritional Status as the Key Modulator of Antioxidant Responses Induced by High Environmental Ammonia and Salinity Stress in European Sea Bass (Dicentrarchus labrax). PLOS ONE, 10(8), e0135091. DOI: 10.1371/journal.pone.0135091

Solé, M., Potrykus, J., Fernández-Díaz, C., \& Blasco, J. (2004). Variations on stress defences and metallothionein levels in the Senegal sole, Solea senegalensis, during early larval stages. Fish Physiology and Biochemistry, 30(1), 57-66. DOI: 10.1007/s10695-004-6786-6

Stephensen, E., Sturve, J., \& Förlin, L. (2002). Effects of redox cycling compounds on glutathione content and activity of glutathionerelated enzymes in rainbow trout liver. Comparative Biochemistry and Physiology Part C: Toxicology \& Pharmacology, 133(3), 435442. DOI: 10.1016/s1532-0456(02)00129-1

Teare, J.P., Punchard, N.A., Powell, J.J., Lumb, P.J., Mitchel, W.D. \& Thompson, R.P. (1993). Automated spectrophotometric method for determining oxidized and reduced glutathione in liver. Clinical. Chemistry. 39 (4), 686-689. PMID: 8472367

Tian, J., Lei, C., Ji, H., Kaneko, G., Zhou, J., Yu, H., Li, Y., Yu,E.M. \&Xie, J. (2017). Comparative analysis of effects of dietary arachidonic acid and EPA on growth, tissue fatty acid composition, antioxidant response and lipid metabolism in juvenile grass carp, Ctenopharyngodon idellus. British Journal of Nutrition, 118(06), 411-422. DOI: 10.1017/s000711451700215x

Tocher, D. R. (2003). Metabolism and Functions of Lipids and Fatty Acids in Teleost Fish. Reviews in Fisheries Science, 11(2), 107-184. DOI: 10.1080/713610925

Valko, M., Rhodes, C., Moncol, J., Izakovic, M., \& Mazur, M. (2006). Free radicals, metals and antioxidants in oxidative stressinduced cancer. Chemico-Biological Interactions, 160(1), 1-40. DOI: 10.1016/j.cbi.2005.12.009

Yengkokpam, S., Pal, A., Sahu, N., Jain, K., Dalvi, R., Misra, S. \& Debnath, D. (2008). Metabolic modulation in Labeo rohita fingerlings during starvation: Hsp70 expression and oxygen consumption. Aquaculture, 285(1-4), 234-237. DOI: 10.1016/j.aquaculture.2008.08.034

Zengin, H., \& Yilmaz, Ö. (2016). Antioxidant defence of the actively feeding Oncorhynchus mykiss (Walbaum 1792) larvae in relation to dietary PUFA and vitamin E contents. Regional Studies in Marine Science, 8, 515-522. DOI: 10.1016/j.rsma.2016.03.003 